Volinec_3@ukr.net

\title{
ENHANCING THE LEVEL OF ECONOMIC DEVELOPMENT OF MULTIMODAL TRANSPORTATION AND GUARANTEEING ITS STABILITY
}

\begin{abstract}
It has been established that the formation of separate enterprises with different types of transport services in a single mechanism of multimodal transportation in accordance with the latest trends in the development of economic and transport systems is a major problem and the main task for our country. It is substantiated that the development of multimodal transport in Ukraine is a promising direction for the formation of an efficient transport and logistics system of the country, and multimodal transportation is a modern concept of cargo transportation according to the logistic principle "from door to door". It is proved that today it is necessary to introduce new principles of formation and coordination of state policy in the field of transport, creation of conditions for ensuring control over the quality of performance of the functions of the relevant executive authorities.
\end{abstract}

Key words: transport infrastructure, logistic terminal, chartering, multimodal transportation, tariff.

Formulation of the problem. To date, there are insufficient logistic terminals of multimodal traffic and their imperfect economic and political regulation. State support for multimodal transport and development of transport and logistics infrastructure is insignificant, so there are the existing constraints on the container transport market and the lack of an investment friendly climate impede their development. Our transport system simply does not ensure the proper volume of multimodal transportations because of insufficient level of development of logistic infrastructure. It simultaneously reduces its competitiveness and hinders the output of Ukrainian products to the world market. In addition, due to the absence of multimodal terminals in most of the territory of Ukraine, $80 \%$ of containers are transported by road. While the average containerization level in the EU is $45 \%$, the container transport industry in Ukraine is at an initial stage of development and is less than $1 \%$.

The possibility of organizing such transportation requires economic and political substantiation, which determines the relevance of the research.

An analysis of recent research and publications and the selection of a part of the previously unresolved problem. Problems of transport activity and multimodal systems were considered in the writings of many domestic and foreign economists. Foreign experience confirms that in the sphere of transport one of the main factors of increasing the level of economic development of multimodal transport and guaranteeing its sustainability.It is worth highlighting also the works of E. Berkum, M. Blimer, L. Wismans, D. Johnson, M. Xoory, I. Chen and other researchers emphasizing the important role and significance of multimodal transport. Researches are devoted to optimization of transport activity and logistics systems, improvement of methodological and practical bases of formation of tariffs for freight traffic in domestic and international communication are described in the writings of domestic scientists, in particular: L. O. Bakayev, A. V. Bazilyuk, N. I. Bogomolova, T. A. Vorkuta, V. M. Gurnaka, M F. Dmitrichenko, N. M. Kolesnikova, P. R. Levkovtsya, K. Onishchenko, V. I. Pasichnyk, P. I. Pidysniy, O. Y. Sokolova, D. L. Tovkun, I. O. Khomenko, V. V Chorniy, S. V. Shiryaeva, V. P. Yanovsky and others. However, the formation of economic and political aspects in the organization of multi-modal door-to-door traffic in mixed interconnections remains poorly investigated and requires attention from academics and practitioners.

The purpose of the article is to justify the economic and political bases of logistic terminals of multimodal transportation in the conditions of globalization in the organization of international mixed cargo transportation. 
Presentation of the main material. The globalization of the economy and the development of modern logistics supply chains demanded the creation of a transport product that would combine services of different types of transport in the most efficient and convenient way for shippers and was formed, first of all, based on the interests of the cargo, rather than individual participants in the process of transportation. This product has become multimodal transportation.

The current economic situation requires the search for new approaches to simplify the procedures for trade in goods, among which the main place is the procedures for moving goods between the seller and the buyer. And in this sense, multimodal transportation of goods is aimed at eliminating technical, organizational, and other barriers during the movement of goods by the links of the supply chain.

In order to maximize the use of transport potential of Ukraine, in particular as a transit state, it is necessary to create a customer-oriented system of transport services and take measures to ensure the efficient organization of the country's transport and road system and to obtain a synergistic effect from the effective combination of potential and capabilities of all modes of transport on the basis of partner-competitive principles during transportation.

Unfortunately, today the low level of intermodal, multimodal transport, and transport logistics development is lacking. In order to ensure a comprehensive solution of issues, in particular, the preparation and implementation of the relevant concept or implementation of the program(s) for the development of multimodal transport and logistics technologies, it requires:

- to improve the regulatory and legal framework for the development of intermodal, multimodal transport, transport logistics;

- to ensure the development of multimodal transport technologies and infrastructural complexes to ensure interaction of different modes of transport;

- to create a network of regular container / multimodal freight trains, synchronized with trains of the EU member states;

- to create a network of multimodal transport and logistic clusters and basic logistics centers, "dry ports", terminals, specialized transshipment complexes, etc.

- to provide intransoperable (interoperability) of the national transport system with the multimodal world transport network, including the railway network of the rails of 1435 millimeters wide;

- to create passenger and cargo-logistics infrastructure complexes as an integral part of multimodal clusters with rail, road, aviation and water transport, in particular by developing a system of multimodal transport and logistic clusters and logistic centers at the borders, in ports and airports in the middle countries, which will provide in 2025 the Ukraine's place in the top 50, and in 2030 in the top 20 world rankings for the index of logistic efficiency (World Bank LPI). (National Transport Strategy 2030) [1, p. 10].

The development of multimodal transportation is a promising direction for the development of the transport system of Ukraine, as it can significantly increase the volume of transportation by its territory with the participation of national transport companies, contributing to increasing the competitiveness of the country in the world'stransport services market, developing a network of existing transport corridors, integrating Ukraine's transport infrastructure with the world transport systems [3, p. 18].

For the development of effective directions for the development of multimodal transport in Ukraine, an important task is to conduct a scientific study of the conceptual apparatus of multimodal transport and related existing conceptual provisions.

After all, the interest in international cooperation in resolving issues related to international transport activities for the provision of mixed (multimodal) freight was determined at the end of the nineteenth century, when the Berne International Convention on the Carriage of Goods by Rail was signed in 1890, which provideda special form a consignment note by which a mixed shipping of goods could be made.

At the same time, the first half of the twentieth century was not sufficiently productive and successful for the international unification of the rules governing the mixed transport of goods, since in 1927 only the Stockholm Conference of the International Chamber of Commerce was held, where the question was raised about the need to unify such transport [7, p. 18]. 
In 1969 At the Tokyo Conference of the International Maritime Committeehas been developed a draft international convention on mixed transport - Tokyo Rules. The ideas of the Tokyo Rules are the basis of the forms of transport documents developed for the registration of mixed freight by international organizations such as FIATA, BIMKO.

It should be noted that so far in the scientific literature there is a discussion about the conceptual apparatus of mixed cargo transportation. The phrase "international mixed cargo transportation" is the official English equivalent of the English term, which is part of the UN Convention on International Multimodal Transport of Goods, developed under the auspices of UNCTAD and adopted by consensus on May 24, 1980 at the Conference of the United Nations full representatives. That is, the key definition of "multimodal" corresponds to the term "mixed" [2, p.102]

The emergence of multimodal systems is primarily due to the global development of container transport in the world market for transport services, as well as the transition of carriers to a discrete type of accounting and freight traffic organization (unified freight unit), which led to an increase in the cost of transportation and the needsfor the formation of modern infrastructure of different types transport [6, p82].

An important direction in the use of multimodal transportation is the combined car and sea transportation. This area is focused on the use of possible multimodal terminals of Ukrainian seaports.

Ukraine is an export-oriented country, however, more than $90 \%$ of export goods are sold under "FOB" terms, ie the transit tariff rate is "torn" at the domestic port of departure on board the ship. This is mainly due to the terms of the contract of sale and, in fact, the absence of its own maritime merchant fleet, whose deadweight has declined significantly in recent years.

The lack of an effective mechanism for the reconstruction of the domestic merchant fleet exacerbates the problem of the country's freight dependence in the organization of international trade and significantly influences the inflow of foreign exchange earnings from the transport of export-import cargo.

Today, for the successful promotion of their products to the markets, it is necessary to have efficient transport services, especially in the maritime areas of cargo transportation. After all, sea transport should be the subject of increased attention from the authorities. In the southern regions of our state, the most important enterprises of the maritime and railway infrastructure are concentrated, which is the basis for conducting now foreign economic activity. Especially because Crimea is temporarily in "strange hands", and Azov is actually a zone of hostilities. The fact that the Kerch Strait is now actually subordinated to the Russian authorities should not be rejected, which is why it requires significant investments here. In particular, the region plays a key role in the development of freight transport and logistics and the growth of the potential of intermodal transport [9, p. 22].

Despite the development of the theoretical and methodological foundations of the formation of the national maritime policy, the adoption of targeted state programs for the development of the merchant navy, the Government of Ukraine has not implemented radical measures for the construction of a new maritime fleet. These programs will not be implemented until the issue of preferential taxation of the shipbuilding business is resolved, the adoption and implementation of the International Register of Ships of Ukraine, the abolition of VAT and customs duties on newly built and purchased fleet, etc. But the implementation of these measures takes time. At present, it is urgently necessary to solve this problem now, in order to reduce freight dependence on other countries and to support export markets for domestic goods.

Exit from this provision is partly due to the creation of modern logistic terminals of multimodal transport, which would carry international cargo "door to door", would have on its balance land transport and charter a foreign navy under the terms of "time charter" . Charging under the terms of a time charter is an agreement on the lease of a ship, when the whole or a part of the vessel is provided at a particular time to the charterer for the carriage of goods in any direction. The shipowner is obliged only to keep the ship in good condition and to pay the crew's salary. The Charger assumes all other expenses (fuel, port duties) and pays the rent to the shipowner. When chartering a vessel for a time charter, the shipowner is obliged, in addition, to equip and complete the ship with the crew, as well as to support the vessel during the period of the time-charter in a seagoing condition, to pay its insurance and 
maintenance of the ship's crew. In the case of chartering a ship by time charter, the captain and other crew members shall be subject to a charterer's order for the operation of the vessel, with the exception of navigational instructions, internal order on the vessel and crew. Or under the terms of "bareboat charter". Chartered on bareboat charter - this is the rental of a ship without a crew. The Charger assumes all expenses for its use and pays the rent to the shipowner. This type of ship charter is widely used when purchasing ships for payments.In this case, the lease agreement is also a contract of sale. Upon completion of the calculations, the charterer becomes the owner of the vessel. Or under the terms of a demise charter. Charging on the terms of a DIMAIM-charter is a lease agreement, when the shipowner passes it to the charterer for a specified period, together with a team whose members become employees of the employer, who assumes all expenses for the operation of the vessel, including the salary of the crew and the rent to the shipowner.

Mixed transport of goods by one carrier in a single document belongs to multimodal transport. Multimodal Logistics Logistics Manager is a provider of transport and distribution services and services for its clients. When performing multimodal transport, these services are performed, as a rule, at the single tariff rate of the entire complex of transport and logistics services.

Logist of multimodal transportations organizes transportation by a single transport document - a bill of lading and is responsible for the process of transportation in general [8, p.69].

The main functions of the logistics manager of multimodal transportation are given in Table 1.

Table 1

The main functions of the operator of multimodal cargo transportation

\begin{tabular}{|c|c|c|c|c|}
\hline \multirow[b]{2}{*}{ Functions } & \multicolumn{4}{|c|}{ Terms of transportation / «Incoterms» } \\
\hline & $\begin{array}{c}\text { DDU } \\
\text { Delivered } \\
\text { Duty Unpaid } \\
\text { (destination is } \\
\text { indicated)the } \\
\text { goods are } \\
\text { delivered to } \\
\text { the customer, } \\
\text { payment of the } \\
\text { duty to the } \\
\text { customer }\end{array}$ & $\begin{array}{l}\text { CIFCost, } \\
\text { InsuranceandF } \\
\text { reight (destina } \\
\text { tionportis } \\
\text { specified): the } \\
\text { goods are } \\
\text { insured and } \\
\text { delivered to } \\
\text { the customer's } \\
\text { port (without } \\
\text { unloading) }\end{array}$ & $\begin{array}{l}\text { DDPDeliver } \\
\text { edDutyPaid } \\
\text { (Destinationi } \\
\text { sindicated) } \\
\text { — the goods } \\
\text { are delivered } \\
\text { to the } \\
\text { customer, } \\
\text { cleared of } \\
\text { duties and } \\
\text { risks }\end{array}$ & $\begin{array}{c}\text { DEQ } \\
\text { DeliveredEx } \\
\text { Quay (portiss } \\
\text { pecified) - } \\
\text { the goods are } \\
\text { delivered to } \\
\text { the vessel and } \\
\text { unloaded } \\
\text { without } \\
\text { customs } \\
\text { clearance }\end{array}$ \\
\hline Determination of the tariff rate & + & + & + & + \\
\hline Insurance of cargo & + & + & + & + \\
\hline Forwarding cargo by land transport & + & + & + & + \\
\hline Operation of own land vehicles (cars, cars) & + & + & + & + \\
\hline Customs operations in the port of transshipment & + & + & + & + \\
\hline Cargo expediting in port of transshipment & + & + & + & + \\
\hline $\begin{array}{l}\text { Offshore ship chartering on "time charter" } \\
\text { terms }\end{array}$ & + & + & + & + \\
\hline $\begin{array}{l}\text { Offshore ship chartering on the conditions of a } \\
\text { bareboat charter }\end{array}$ & + & + & + & + \\
\hline $\begin{array}{l}\text { Offshore ship chartering on"demise- } \\
\text { charter"terms }\end{array}$ & + & + & + & + \\
\hline Agency agent of a ship in the port of departure & + & + & + & + \\
\hline $\begin{array}{l}\text { Marine operation from the port of departure to } \\
\text { the port of destination (the functions of the } \\
\text { logistics manager of the vessel) }\end{array}$ & + & + & + & + \\
\hline Ship's agent in port of destination & + & + & + & + \\
\hline Cargo expediting in the destination port & + & - & + & + \\
\hline $\begin{array}{l}\text { Import and licenses, permits, customs } \\
\text { payments }\end{array}$ & - & - & + & + \\
\hline $\begin{array}{l}\text { Expediting cargo from the port of destination to } \\
\text { the consignee }\end{array}$ & + & - & + & - \\
\hline
\end{tabular}


The logistics manager of multimodal transportation, in accordance with the contract, concludes agreements with the actual carrier and is charged with them for the work performed, is responsible to his client for the storage of the cargo throughout the transportation route. The responsibility of the logist for the load is determined from the moment of receipt of the load in its charge (in the charge) up to the time of delivery to the recipient.

The logistics manager of multimodal transportation, in accordance with the contract, concludes agreements with the actual carrier and is charged with them for the work performed, is responsible to his client for the storage of the cargo throughout the transportation route. The responsibility of the logist for the load is determined from the moment of receipt of the load in its charge (in the charge) up to the time of delivery to the recipient.

However, such preforms of the Knesset do not fully eliminate the problem of introducing a single international liability regime for international multimodal transport under a single transport document.

The decision to deal with international multimodal transport is likely to be the "Rotterdam Rules" adopted by the United Nations General Assembly on 11.12.2008 in New York, but they have not yet been ratified by the participating countries.

Thus, for today, multicast transport rules are governed by UNCTAD rules and the multimodal transport document (bill of lading), Multiloc-95 or Bill of Lading [5, p.62].

Consequently, we can state that today, there is a single legal system for the interaction of different modes of transportin the development of the basics of multimodal management.

For the consignor, a single transport document (bill of lading) has certain advantages. In particular, most banks in the world use multimodal bill of lading as a commodity-management document. The seller, wichhave shipped the goods from the warehouse to the automobile, railway or sea transport, receives a multimodal bill of lading from the logistian, and may, if he presented this bill of lading to the bank, to open a letter of credit for obtain a contract for the price of the goods. In turn, the buyer, and in most cases it is a foreign trade company, wichhave received a multimodal bill of lading, may offer the goods specified therein on the market long before the goods are loaded onto the boat. Estimation of economic efficiency of management of transport process of multimodal transportations involves the definition of the criterion of competitiveness of the selected logistic scheme [4, p. 26].

Such a criterion may be the tariff rate. Since the price of products in the commodity market of consumers $(Ц n p)$ is determined on the basis of demand and supply, it should be greater or equal to the cost of production at the place of its production, taking into account the customs and initial operations $(\lfloor n)$, the cost of the tariff rate $(d m p)$ of delivery of the goods to the port destination and cost (Цот) of the recipient of the cargo for customs, cargo operations and delivery of the goods to the buyer's warehouse (if the invoice contracts are concluded on CIF terms.

$$
\bigsqcup_{n p}=\bigsqcup_{n}+d_{m p}+Ц_{o m}
$$

The allowable value of the tariff rate shall be less than or equal to the difference between the market price of products $(\lfloor n)$ and the production price, taking into account the initial and customs operations at the point of departure and the cost of the consignee for the customs, cargo operations and delivery of the cargo to the buyer's warehouse:

$$
d_{m p}=Ц_{n p}-Ц_{n}-Ц_{o m}
$$

Today it is difficult for transport companies of Ukraine to ensure the transportation of goods under such a harsh competitive environment in the international transport services market. Therefore, virtually all export goods are sold on FOB terms - the place of shipment in the port of transshipment on board the ship. That is, the logistic transport scheme is torn off in seaports, and more than $70 \%$ of the transport tariff rate becomes a gain for foreign carriers. This is due to the fact that domestic rail transport, seaports operate in conditions of monopoly established by the state 
tariffs and only maritime transport operates in the freight market. But due to the actual absence of its own merchant fleet, exporters are forced to sell their goods on FOB terms, which leads to freight dependence on other countries, and in many cases to lower sales prices by increasing the freight component of foreign charterers. An exit from this situation is seen in the chartering of sea-going vessels on terms of "time-charter", "bareboat-charter" and "dimay-charter" by Ukrainian logisers with the organization of delivery of freely exported goods on their own. But such an approach will be possible if the cost of chartering ships, fuel and port duties per tonne of cargo will be lower than the market freight rate. With regard to port charges, the rates for all of their components (ship, berths, pilots, administrative fees, etc.) are set by the state in virtually all countries of the world. Chartered timerates and fuel costs are determined on the world's freight and fuel markets.

The calculation of a competitive tariff rate taking into account the optimal choice of the route of cargo delivery and forecasts of the freight market is carried out with the use of economic and mathematical modeling. As already noted above, the through rate consists of the sum of tariff rates for land transport, charter rates and other costs of transshipment complexes of sea merchant ports, market timing charter rates of seagoing vessels, fuel costs, port dues and own expenses, taking into account expedition costs, brokerage, agent and other operations that are used throughout the logistics chain of cargo transportation.

Then the minimum market tariff rate can be determined by the formula:

$$
d_{m p}=(1+p) \frac{A}{B} \leq Ц_{n}-Ц_{n p}-Ц_{o m} \rightarrow \min ,
$$

$d_{m p}$ - tariffratedependingonthechosenterm "Incoterms";

$A$ - the amount of expenses incurred by the participants in the carriage of goods in the calculation of the ship's batch.

$$
A=\left[R_{i n}^{3}+R_{i n}^{n}+R_{i m}^{c h}+R_{i n m}^{p c}+R_{i n m}^{t}+R_{i n m}^{O M K}\right] f_{y} C_{m} C_{r j} J_{i n m j},
$$

$R_{\text {in }}^{3}$ - Logistics costs for cargo transportation by rail from the second consignor to the $n$-th port of transshipment. They are determined on the basis of the railway tariffs of the operator, which has its own wagon in terms of the volume of the ship's batch;

$R_{i n}^{n}$ - costs of the transshipment complex in the $\mathrm{n}$-th port of transshipment (according to the chord rates and the cost of other works performed by the port);

$R_{i m}^{c h}$ - expenses for chartering a marine vessel in a time charter;

$R_{i n m}^{p c}-$ port fees in nth tm-m ports are determined according to the fares of the ship's country of destination;

$R_{\text {inm }}^{t}$ - the cost of fuel, is determined in accordance with the rates on the fuel market;

$R_{\text {inm }}^{O M K}$ - costs of the logistics manager of multimodal transportation for servicing their own wagons, forwarding, brokerage, agency and other activities - are determined on the basis of agreements concluded by the logistics manager with their contractors.

$f_{y}$ - optimal transportation line;

$i$ - consignor;

$n$ - port of cargo handling; $f$ - line of transportation;

$\mathrm{r}$ - The type of chartered vessel for f-line of transportation;

$\mathrm{j}$ - port of the consignee from the other shipper;

jinrj - boolean change equal to 1 if defined sequence

jinrj, otherwise it equals 0 .

$B=\alpha_{y} D_{y} f_{i j} C_{r n} C_{r j} J_{i n m j},(5)$

$\alpha_{y}$ - coefficient of use of the carrying capacity of r-th vessel;

$D_{y}$ - load capacity r-th vessel. 
$C_{r n}$ - matrix of liability types of ships $r=\overline{1, R}$ ports of transshipment $\mathrm{n}=\overline{1, \mathrm{~N}}$;

$C_{r j}$ - liability of vessel types $r=\overline{1, R}$ ports of the consignee of the cargo[8, p.79].

Conclusions and perspectives of further exploration. Thus, a generalized economicmathematical model for determining the optimal market rate for multimodal transport of goods is proposed. The proposed method of sequential analysis of options guarantees the choice of the minimum market rate and its close to the value of the criterion of permissible limits [10, p.17].

For multimodal transport, the future and most countries are already talking about it. Providing great attention to the development of multimodal transport in Ukraine will provide new opportunities for the development of the entire transport and logistics system of Ukraine. The first steps have been taken and there are strong expectations that the implementation of the transport strategy of 2030 and the proposed methodology will lead to qualitative changes in the transport sector.

Ukraine already has a methodological basis for improving the mechanism of combined automobile (rail) and sea transport, serving as one of the main stages of improving the country's transport and logistics system.

Positive changes in the economic and political situation of the country will further enable the formation of multimodal terminals at other sea ports, where they have not yet been introduced, will ensure the servicing of new lines of transportation, will reduce the time of delivery of goods, and significantly reduce the financial costs of transportation.

\section{Список використаних джерел:}

1. Національна транспортна стратегія України на період до 2030 року (Проект) [Електронний ресурс] Режим доступу: https://mtu.gov.ua/news/28581.html.

2. Волинець Л.М. Удосконалення взаємодії різних видів транспорту в сучасних умовах / Л.М. Волинець, В.М. Гурнак // Економіка та управління на транспорті. - 2018. - № 6. - С.100-106.

3. Гурнак В.М. Обгрунтування необхідності зміни приоритетів інвестування розвитку інфраструктури різних видів транспорту в сучасних умовах/ В.М. Гурнак, Л.М. Волинець, М.В. Гурнак// Управління проектами, системний аналіз та логістика. Серія «Економічні науки». -2017. - №9. - С. 33-39.

4. Мультимодальні перевезення: сучасні технології. [Електронний ресурс]. - Режим доступу: http://www.expresstrans.net/gruzak.html.

5. Никифоров В.С. Мультимодальные перевозки и транспортная логистика. Учебное пособие./ В.С.Никифоров. - Новосибирск: НГАВТ, 1999. - 103 с.

6. Соколова О.С. Теоретичні основи організації та розвитку мультимодальних перевезень в Україні / О.Є. Соколова // Економічний простір.- 2014. - № 83. - С. 91-103.

7. Обзор морского транспорта-2016 / Конференция ООН по торговле и развитию - Нью-Йорк, Женева: ООН, UNCTAD - 2016. - $133 \mathrm{c}$

8. Підлісний, П. І. Роль контейнеризації змішаних вантажних перевезень у розвитку світової торгівлі / П. І. Підлісний, Н. О. Паткевич, Ю. В. Цвєтов // Економічний форум. - 2016. - № 3. - С. 67-81.

9. Хоменко І.О. Проблеми розвитку мультимодальних перевезень в Україні та альтернативи, щодо їх вирішення / І.О. Хоменко, Л.М. Волинець // Тези доповідей конференції розвиток інноваційноінтегрованих структур у вимірі формування інноваційно-орієнтованої моделі економіки (21-22 березня 2018 року). - Кропивницький: Центральноукраїнський національний технічний університет, 2018. - С.70.

10. Шкарлет С.М. Імплементація європейських стандартів як основа механізму удосконалення державного регулювання у транспортній галузі / С.М. Шкарлет, І.О. Хоменко, Л.М. Волинець // Управління проектами, системний аналіз і логістика. Ч.2: Серія «Економічні науки» - К.: НТУ, 2018. - Вип. 20. - С.55-59.

\section{References:}

1. Natsionalna transportna stratehiia Ukrainy na period do 2030 roku [National transport strategy of Ukraine for the period up to 2030] (n.d.) mtu.gov.ua. Retrieved from https://mtu.gov.ua/news/28581.html (in Ukr).

2. Gurnak, V.M. \& Volynets L.M. (2018). Udoskonalennia vzaiemodii riznykh vydiv transportu v suchasnykh umovakh [Improvement of the interaction of different types of transport in modern conditions] Ekonomika ta upravlinnia na transporti - Economics and Transport Management, 6 (in Ukr).

3. Gurnak, V.M. \& Volynets L.M. \& Gurnak M.V. (2017). Obhruntuvannia neobkhidnosti zminy pryorytetiv investuvannia rozvytku infrastruktury riznykh vydiv transportu $\mathrm{v}$ suchasnykh umovakh [Justifying the need to change priorities of investing in the development of infrastructure of different types of transport in modern conditions] Upravlinnia proektamy, systemnyi analiz i lohistyka. Ch.2: Seriia «Ekonomichni nauky» - Project management, systems analysis and logistics. Part 2: Series «Economics», 9, 33-39 (in Ukr).

4. Multymodalni perevezennia: suchasni tekhnolohii [Multimodal transportation: drying of technologia] Retrieved from http://www.expresstrans.net/gruzak.html. 
5. Nikiforov, V.S. (1999). Multimodalnye perevozki i transportnaya logistika [Multimodal transport and transport logistics]. Novosibirsk: Siberian State University of Water Transport.

6. Sokolova, O.E. (2014). Teoretychni osnovy orhanizatsii ta rozvytku multymodalnykh perevezen v Ukraini [Theoretical basis of organization and development of multimodal transportation in Ukraine]. Ekonomichnyi prostir - Economic space, 83, 91-103 (in Ukr).

7. Obzor morskogo transporta-2016 [Sea Transport Review-2016] Konferenciya OON po torgovle i razvitiyu - UN Conference on Trade and Development (p. 133). New York, Geneva: UN, UNCTAD (in Russ).

8. Pidlisny, P.I., Patkevich, N.O. \& Tsvetov, Yu.V. (2016). Rol konteineryzatsii zmishanykh vantazhnykh perevezen u rozvytku svitovoi torhivli [The role of containerization of mixed freight transport in the development of world trade]. Ekonomichnyi forum - Economic forum, 3, 67-81 (in Ukr).

9. Khomenko, I. O. \& Volynets, L.M. (2018). Problems of multimodal transport development in ukraine and alternatives to their solution. Proceedings from: Rozvytok innovatsiino-intehrovanykh struktur u vymiri formuvannia innovatsiinooriientovanoi modeli ekonomiky: zbirnyk tez dopovidei Mizhnarodnoi naukovopraktychnoi internet-konferentsii - Development of innovation-integrated structures in the measurement of the formation of an innovation-oriented model of economy: a collection of abstracts of the International Scientific and Practical Internet Conference, Kropivnitsky: Exclusive Systems, p.17.

10. Shkarlet, S.M. \& Khomenko, I.O. \& Volynets L.M. (2018). Implementatsiia yevropeiskykh standartiv yak osnova mekhanizmu udoskonalennia derzhavnoho rehuliuvannia u transportnii haluzi [Implementation of European standards as the basis of the mechanism for improving state regulation in the transport sector]. Upravlinnia proektamy, systemnyi analiz i lohistyka. Ch.2: Seriia «Ekonomichni nauky» - Project management, systems analysis and logistics. Part 2: Series «Economics», 20.

\section{ВОЛИНЕЦЬ Людмила Миколаївна,}

к. е. н., доцент,

доцент кафедри транспортного права та логістики,

Національний транспортний університет, м. Київ, Україна

Volinec_3@ukr.net

\section{ПІДВИЩЕННЯ РІВНЯ ЕКОНОМІЧНОГО РОЗВИТКУ МУЛЬТИМОДАЛЬНИХ ПЕРЕВЕЗЕНЬ ТА ГАРАНТУВАННЯ ЙОГО СТАЛОСТІ}

Анотація.

Актуальність. Сучасна економічна ситуачія вимагає пошуку нових підходів до спрощення процедур торгівлі товарами, серед яких головне місие посідають процедури переміщення товарів між продавием та покупием. I в иьому сенсі саме мультимодальні перевезення вантажів $\epsilon$ спрямованими на усунення технічних, організаційних, та інших бар'єрів під час переміщення вантажів ланками логістичного ланцююгу постачань.

На сьогоднішній день транспортним підприсмствам України важко забезпечувати перевезення вантажів в умовах такого жорсткого конкурентного середовища на міжнародному ринку транспортних послуг. Тому практично всі експортні товари продаються на умовах FОВ місие передачі вантажу в порту перевалки на борту судна. Тобто логістична транспортна схема розривається в морських портах. Це пов'язано з тим, щзо вітчизняний автомобільний та залізничний транспорт, морські порти працюють в умовах монопольно встановлених державою тарифів $і$ лише морський транспорт праџює в умовах фрахтового ринку. Але у зв'язку з фактичною відсутністю власного торговельного флоту експортери вимушені продавати свої товари на умовах FОВ, що призводить до фрахтової залежності від інших держав, а в багатьох випадках до зменшення иін продажу за рахунок збільшення фрахтової складової іноземних фрахтувальників.

Формування національної морської політики, прийняття иільових державних програм розвитку торговельного флоту, урядом Украӥни не здійснено кардинальних заходів щзодо будівництва нового морського флоту. Ці програми не будуть виконуватися доти, доки не буде вирімене питання пільгового оподаткування суднобудівного бізнесу, прийняття $i$ впровадження Міжнародного реєстру суден Украӥни, скасування ПДВ і митного збору на новозбудований та придбаний флот тощо. Наразі, вкрай необхідно вирішити дану проблему зараз, щяоб зменшити фрахтову залежність від інших держав та підтримувати експортні ринки для вітчизняних товарів.

Мета. Обгрунтування економічних та політичних засад діяльності логістичних терміналів мультимодальних перевезень в умовах глобалізаиї̈ при організачії міжнародних змішаних перевезень вантажів.

Методи дослідження. Методи економічного, системного та порівняльного аналізу.

Результати. В статті розглянуто основні теоретичні та практичні аспекти формування економічного та політочного розвитку мультимодальних перевезень. Проведено обтрунтування 
заходів, щодо ефективних умов фрахтуванні морських суден та покращення транспортної галузі в Україні. Проаналізовано методичні положення, щяодо визначення оптимальної ринкової тарифної ставки при мультимодальних перевезеннях вантажів. Досліджено розрахунки конкурентоспроможної наскрізної тарифної ставки з урахуванням оптимального вибору маршруту доставки вантажу та прогнозів фрахтового ринку.

Новизна. Визначено та охарактеризовано ефктивні умови фрахтуванні морських суден: «тайм-чартеру», "бербоут-чартеру» та "димайз-чартеру" українськими логістами з організачією доставки вантажів, що експортуються, власними силами при умові, що витрати на фрахтування суден, паливо й портові збори з розрахунку на одну тонну вантажу будуть нижчими за ринкову фрахтову ставку. Запропонована узагальнена економіко-математична модель визначення оптимальної ринкової ставки при мультимодальних перевезеннях вантажів та метод послідовного аналізу варіантів, який гарантує вибір мінімальної ринкової ставки та близьких до неї за значенням критерію допустимих обмежень.

Висновок. На основі проведеного аналізу, було доведено, що розвиток мультимодальних перевезень в Україні є перспективним напрямом формування ефективної транспортно-логістичної системи країни, а мультимодальні перевезення є сучасною концепцією транспортування вантажів за логістичним принципом «від дверей до дверей». Доведено, щэо на сьогодні є необхідним впровадження нових принципів формування та координащії державної політики в галузі транспорту, створення умов забезпечення контролю за якістю виконання функиій відповідних органів виконавчої влади.

Запропоновано методичні положення розвитку мультимодальних перевезень в Україні. Формування оптимальних аспектів доставки вантажів на умовах взаємодії різних видів транспорту дозволить суттєво скоротити час та фінансові витрати на міжнародні перевезення вантажів, а також сприятиме підвищенню економічного рівня розвитку країни.

Ключові слова: транспортна інфраструктура, логістичний термінал, фрахтування, мультимодальні перевезення, тариф.

Одержано редакиією: 30.09 .2018 Прийнято до публікаиії: 22.10.2018 